\title{
Building a Circular Economy Model for Managing Exploitation of Household Used Devices \\ sciendo on the Example of Washing Machine Driven by DC Motor Along with Components
}

doi:10.2478/mape-2021-0028

Date of submission to the Editor: 04/2021

Date of acceptance by the Editor: 08/2021

\section{Usman Saleem}

Zaheer Sons, Rawalpindi, Pakistan

Jan Kaźmierczak

ORCID ID: 0000-0002-2459-470X

Silesian University of Technology, Poland
MAPE 2021, volume 4, issue 1, pp. 309-316

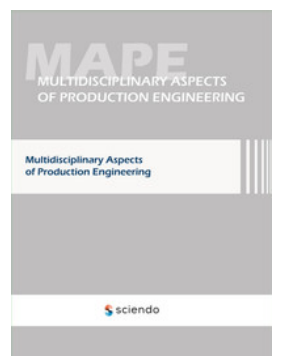

\section{INTRODUCTION}

Most commonly, in the more and less distant past, the linear model of managing the resources that make up the technical human environment (sometimes called the Technosphere) follows the pattern of "take, produce, use, throw away" (Kampker et al., 2011). In this article, the authors attempted to join the increasingly extensive debate of scientists and practitioners on the need and possibility of replacing the above-mentioned linear model with a model offered by the circular economy concept (European Parliament, 2015), (Gerholdt, 2017). In this concept, the key element is the assumption that materials and raw materials, which according to the linear model are treated as waste after the end of the use of the technical means by the final buyer (user), are returned to the production system in the circular economy concept, which contributes to both to save energy, recover raw materials and materials (in recycling processes), as well as reduce labour inputs (Elwert et al., 2016).

The discussion on the possibilities of applying the concept of "closed circuit" undoubtedly requires theoretical considerations, but it cannot do without showing as many and diverse as possible presentations of the practical applications of this concept. Such diversity should include - above all - a wide range of products, consuming raw materials and materials, energy and labour resources in the production process, while the description of examples should focus on the inventory of "primary" resource streams used in the production process, on the other hand, and: on a detailed analysis of resources susceptible to "recycling" in the manufacturing process.

The subject of the research project presented in this study is to assess the susceptibility to the use of the "Circular economy" model for a specific class of technical means, which consists of machines and devices used in households. As a representative of this class of technical objects were selected for the purposes of research presented below is a domestic washing machine. For just 
such a technical object, an attempt was made to develop a circular economic model, taking into account the complexity of the technical object in this model, including the presence of various categories of components in such an object: assemblies, sub-assemblies, and parts (elements). Particular attention has been paid to the tests carried out so far, described below, on the motor driving the washing machine and its components and accessories (bearings, copper wire, and shaft). The previous practice of washing machine manufacturers in managing the supply chain of components was recognized, as well as their own and the experience described in the available literature in the field of using techniques for repair, disposal (shredding), recycling, regeneration, and reuse of engine components (Sousa and Miguela, 2017).

Certainly, the existence of possibilities is not equivalent to the existence of needs. The problem of needs can be even seen as an autonomous challenge in engineering (Kaźmierczak, 2017). In this paper, both the identification of needs and the identification of possibilities of fitting the needs were the subject of consideration.

The next chapter briefly introduces the results of initial (primary) research which were carried on in Pakistan. This research was focused on recognizing the possibilities to consider and analyse the processes of manufacturing washing machines according to the "Circular Economy" concept.

\section{METHODOLOGY OF RESEARCH}

The presented studies were carried out at the Gujranwala washing machine manufacturing plants in Pakistan and aimed to identify and analyse the production processes at these plants. The main objects studied in the research were the washing machine itself and the DC electric motor driving the motor and its components. The basic research methods were:

$\circ \quad$ the method of direct participant observation (in the field of manufacturing processes),

- personalized interview method (in terms of the participation of plant employees in the implementation of the tested processes).

The persons interviewed during the research were selected as being highly experienced in planning, organizing, and managing manufacturing processes. Additionally, their practical knowledge and skills concerning the product of the plants (household washing machines) and various problems concerned with the use, service, and maintenance of washing machines were treated as a basing criterion of choosing respondents in the interviews.

As the background of the interviews, it was initially assumed that washing machines and their components would be refurbished, reused, or recycled again. These partial processes were treated as elements consisting of the intended to be built up a model of manufacturing, using, and servicing the household washing machines according to the circular economy (CE) concept. 


\section{Background and plan of the research}

The introduced research has been focused on the effects of implementing into production the new development of a BLDC motor and the maintenance conditions of this motor to expand the washing machine lives up to 5 years. Additionally, it was assumed that thanks to applying the CE concept, it will become possible to return the maximal amount of material to the manufacturing cycle and then to save a significant amount of resources (Heshmati, 2017).

The research activities planned to be carried out were taken into account some conditionings of technological nature, like:

- the DC motor consists of major parts such as a rotating shaft, bearings, and copper wire,

- the rolling bearings cannot be easily reused but can be melted down and reused in a new engine.

In common practice, industrial companies operate via their service networks by collecting reusable items such as the DC motor and its components (in the case of washing machines) in the micro stage. At the meso level, the internal parts of the DC motor are or can be repaired.

Based on the observations of manufacturing processes and discussions with experts, it was assumed that the macro-level offers the appropriate circumstances of implementing a circular economy-based model.

In the DC motor, a particular subject of investigations, bushings are eliminated according to the concept named BLDC (Brushless DC Motor). It is a significant feature due to extending the time between services because the bushings are especially often damaged by water. Additionally, the BLDC assures a significant limitation of the noise level. Thanks to applying such a solution, the engine maintenance will be carried out for a period of 5 years of warranty.

In preparing the plan of the initial as well as further research, the need was taken into account for techniques such as recycling, leasing, and reuse in manufacturing. The manufacturing and design sectors face challenges in delivering sustainable solutions.

The opportunity of visiting Super Asia washing machine company in Pakistan has offered to gather observations of numerous original problems, appearing and recorded in DC motors during the running of the washing machines. For instance, various DC motor electric kits' consisting of resistors, capacitors, and transformers were damaged by current variations. The presence of water inside the motor was a significant source of damage or jams to the carbon bushes. Copper winding could be got short, and finally, the motor can burn. All these factors were included in the plan of the primary stage of research as having a potential impact on possibilities of building the CE - based model for the household washing machines.

It was also assumed that - according to the requirements of PhD program - the primary research will be completed in future by other research activities focussed, for instance, on investigating other models like a model of the supply chain, product range model, usage model, maintenance model and - last but 
not least - model of the end of life of a technical object, i.e. a model of excluding such an object from its intended use (Banaité, 2016).

\section{Description of the research and discussion of results}

While collecting data in Super Asia washing machine company, the discussion with a Manager of an R\&D department was the source of primary, technologyoriented information. This expert described different types of motors used in the washing machines, ceiling fans, cooler fans. He also described the technical structure of these motors, consisting of components like rotating shaft, carbon brushes, bearings, electric kit (capacitors, resistors magnet etc.). The motors of Super Asia were working from $12 \mathrm{~V}$ to $220 \mathrm{~V}$. Another motor was in the developing phase and was based on BLDC (Brushless motor) concept, having no carbon bushes. This new motor is intended to be waterproof and noiseless. This motor is of DC power supply and will work on $24 \mathrm{~V}$.

The problems of maintenance and service of the washing machines were the next main topic of discussions with the experts of Super Asia. The possibilities and limitations of offering a five-year warranty were considered as strongly implied by proper maintenance and service procedures. In this context, the need for an appropriate system dedicated to collect and store service data was mentioned.

The last element of the research program carried out by the Super Asia company was the preparation of a list of washing machine components that could potentially and should be included in the preparation of the CE model, using the "checklist" formula.

It was decided that such a list, in the case of an electric motor driving a washing machine, would include:

○ a magnet,

○ rotary shaft,

- copper wire winding,

- electronic card (instrumentation).

The DC motor components in the production process are checked physically or using a dedicated measuring set (multimeter).

The checklist contains information on serious operational problems such as winding overheating problems or rotating jam problems with consequent magnet, winding, and/or electronic failure.

The checklist also provides information on which parts will be recycled, reused, or refurbished (according to industry requirements).

Table 1 shows the example of the checklist in the form of the so-called "Maintenance table", prepared under the template used by the Super Asia company and describing the maintenance conditions of the DC motor used in a household washing machine. 
Table 1 Maintenance conditions along inspection years for DC motor

\begin{tabular}{|c|c|c|c|c|c|}
\hline Part No & $\begin{array}{l}1^{\text {st }}-5^{\text {th }} \\
\text { year }\end{array}$ & Reasons & $\begin{array}{c}\text { Action } \\
\text { plan }\end{array}$ & Checking & $\begin{array}{c}\mathrm{CE} \\
\text { model }\end{array}$ \\
\hline 1. Magnet & Crack & Load Dust & $\begin{array}{l}\text { Replace } \\
\text { magnet }\end{array}$ & $\begin{array}{l}\text { Physical } \\
\text { inspection }\end{array}$ & $\begin{array}{l}\text { Magnet } \\
\text { reuse }\end{array}$ \\
\hline 2. Rotar & $\begin{array}{l}\text { Sheet } \\
\text { slips }\end{array}$ & Dust & $\begin{array}{l}\text { Replace } \\
\text { sheet }\end{array}$ & $\begin{array}{l}\text { Physical } \\
\text { inspection }\end{array}$ & $\begin{array}{l}\text { Shaft } \\
\text { recycle, } \\
\text { reuse, } \\
\text { refurbish }\end{array}$ \\
\hline 3. Copper w & $\begin{array}{l}\text { Blackish } \\
\text { colour }\end{array}$ & $\begin{array}{l}\text { High } \\
\text { current } \\
\text { makes } \\
\text { motor heat } \\
\text { up }\end{array}$ & $\begin{array}{l}\text { Copper } \\
\text { wire wind } \\
\text { again }\end{array}$ & $\begin{array}{l}\text { Multimeter } \\
\text { to check } \\
\text { short circuit } \\
\text { of resistor }\end{array}$ & $\begin{array}{l}\text { Copper } \\
\text { wire } \\
\text { reuse, } \\
\text { recycle }\end{array}$ \\
\hline 4. Electronic card & $\begin{array}{l}\text { PCB } \\
\text { board } \\
\text { damaged }\end{array}$ & $\begin{array}{l}\text { High } \\
\text { current }\end{array}$ & $\begin{array}{l}\text { Replace } \\
\text { burn PCB } \\
\text { board }\end{array}$ & $\begin{array}{l}\text { Multimeter } \\
\text { to check } \\
\text { current }\end{array}$ & $\begin{array}{l}\text { Electronic } \\
\text { card } \\
\text { recycle }\end{array}$ \\
\hline 5. DC Motor & $\begin{array}{l}\text { Dust } \\
\text { gathered }\end{array}$ & $\begin{array}{l}\text { Jamming } \\
\text { issues }\end{array}$ & $\begin{array}{l}\text { Blower } \\
\text { used }\end{array}$ & $\begin{array}{l}\text { Physical } \\
\text { inspection }\end{array}$ & $\begin{array}{l}\text { DC motor } \\
\text { refurbish, } \\
\text { reuse }\end{array}$ \\
\hline
\end{tabular}

Source: Super Asia washing machine company, Gujranwala, Pakistan

The results of the initial phase of research, as briefly introduced in this chapter, proved - in the opinion of authors of this study - that the adequate set of data that would be the base for developing the CE oriented model of producing and exploiting the chosen example of a technical object, i.e. for a household washing machines, is obtainable. Therefore, the research project aimed at using the circular economy concept as the basis for creating a process model for the production and use of a selected group of technical objects can be considered feasible.

\section{PLAN OF FURTHER RESEARCH}

The key intention of the authors of this study is to use the results of the primary research presented above as the basis for further research, the aim of which will be to prepare a doctoral dissertation in the problem area, consistent with the title of this study.

As important steps of realizing the intended doctoral dissertation, the following research tasks are assumed to be completed:

1. Literature research on the recognition and description of the Circular Economy concept and the analysis of the possibilities of applying this concept in various practice areas, including described in the literature cases of such applications. 
2. Literature research in the field of identification of various models of business activity and analysis of the possibility of using these models in various management tasks.

3. Literature research in the field of identification of various models of managing the operation of machines and devices.

4. Identification of a set of tasks related to the management of machinery and equipment operation selected for further research on a group of such objects.

5. Development of the concept of how to apply the Circular Economy model as the basis for business activity in the management of the operation of a selected group of technical facilities.

6. Researching to collect data resources describing selected aspects of the operation of a previously defined group of technical objects.

7. Development of a formalized business model for managing the operation of a selected group of facilities following the concept of the Circular Economy.

8. Development of a prototype IT tool for supporting the management of business activities aimed at managing the operation of a selected group of facilities following the developed model.

9. Verification of the developed model by testing the developed supporting tool.

The authors of this study are assuming to present results obtained in the successive steps of the above-presented research plan in their future publications.

\section{CONCLUSIONS}

It is reasonable to assume that the Circular Economy approach will be passing in the nearest future step-by-step from the field of scientific/theoretical considerations to practically applicable solutions.

To make this possible, it is necessary to demonstrate, using as many different examples as possible, the practical implementation of this model. In addition, it seems advisable to show potential stakeholders the positive effects of using the CE concept and the possibility of IT support for the above-mentioned implementation. The authors of this study assume that the implementation of the described research intention not only will form the basis of the doctoral dissertation but also will show the practical usefulness of the CE concept.

\section{REFERENCES}

Andrews, C. J. (2013). Empowering sustainable consumption. IEEE Technology and Society Magazine.

Ashutosh O. Okorie C. Turner, F. C. M. M. T. (2017). A review of data driven approaches for Circular Economy in manufacturing. In $18^{\text {th }}$ European Roundtable for Sustainable Consumption and Production, ERSCP.

Banaite, D., \& Tamošiuniene, R. (2016). Sustainable development: The circular economy indicators' selection model. Journal of Security and Sustainability Issues, 6(2), pp. 315-323. 
Banaité, D. (2016). Towards Circular Economy: Analysis of Indicators in the contect of sustainable development. Social Transformations in Contemporary Society, 4(4), pp. 142-150.

Elwert, T., Goldmann, D., Römer, F., Buchert, M., Merz, C., Schueler, D., \& Sutter, J. (2016). Current developments and challenges in the recycling of key components of (Hybrid) electric vehicles. Recycling. MDPI AG.

Euro Parliament (2017). Circular economy: definition, importance and benefits. http://www.europarl.europa.eu/news/en/headlines/economy/20180514STO0340 6/blockchain-technology-we-aspire-to-make-eu-leading-player

Gerholdt, J. (2017). The 5 Business Models that Put the Circular Economy to Work. GreenBiz, pp. 5-7.

Heshmati, Almas. (2017). A review of the circular economy and its implementation. International Journal of Green Economics. 11. 251.

Jeswiet, J., \& Hauschild, M. (2005). EcoDesign and future environmental impacts. Materials and Design, 26(7), pp. 629-634.

Kampker, A., Franzkoch, B., Wesch-Potente, C., \& Brokelmann, I. (2011). ReBox-Pool Innovative logistic concept based on a modular loading carrier concept. In 2011 $17^{\text {th }}$ International Conference on Concurrent Enterprising, ICE 2011 - Conference Proceedings.

Kaźmierczak, J. (2017). Engineering of Needs (Eon): The Role of Identifying and Analyzing Needs in Engineering and Engineering Management. DEStech Transactions on Social Science, Education and Human Science, (icss).

Kirchherr, J., Reike, D., \& Hekkert, M. (2017). Conceptualizing the circular economy: An analysis of 114 definitions. Resources, Conservation and Recycling. Elsevier B.V.

Lindahl, M., \& Sundin, E. (2013). Product design considerations for improved integrated product/service offerings. In Handbook of Sustainable Engineering pp. 669-689. Springer Netherlands.

Lopes de Sousa Jabbour, A. B., Jabbour, C. J. C., Godinho Filho, M., \& Roubaud, D. (2018). Industry 4.0 and the circular economy: a proposed research agenda and original roadmap for sustainable operations. Annals of Operations Research, 270(1-2), pp. 273-286.

Morseletto, P. (2020). Targets for a circular economy. Resources, Conservation and Recycling, 153.

Pieroni, M. P. P., McAloone, T. C., \& Pigosso, D. C. A. (2019, April 1). Business model innovation for circular economy and sustainability: A review of approaches. Journal of Cleaner Production. Elsevier Ltd. https://doi.org/10.1016/j.jclepro.2019.01.036

Sousa-Zomer, T. T., Magalhães, L., Zancul, E., Campos, L. M. S., \& Cauchick-Miguel, P. A. (2018). Cleaner production as an antecedent for circular economy paradigm shift at the micro-level: Evidence from a home appliance manufacturer. Journal of Cleaner Production, 185, pp. 740-748. 
Abstract: In the article, the authors describe, using the example of a selected class of technical means, their concept of replacing the "classical" linear management (exploitation) model with a circular economy (CE) model. An example of an object for which the authors plan to test the feasibility of the concept presented above is a household washing machine driven by a DC motor. The description of this object included in the article considers its complexity and multiplicity of assemblies, subassemblies, and elements. The DC electric motor driving the washing machine was considered the most important from the point of view of the created model, especially in terms of the possibility of maintenance and repair. For such an engine, the article presents the maintenance and disposal model as elements of the concept of building a 'circular' business model. The authors assumed that the formal basis for such a model would be the so-called circular model. The methodology and plan of the research carried out at Super Asia washing machine company in Pakistan were introduced, and the research results were shown. With the use of these results, an attempt was made to assess the requirements that the application of the CE business model places on manufacturers of a selected class of devices, both in their manufacture, repair, sharing and dematerialization. The concept of further research is described at the end of the article.

Keywords: Circular economy, exploitation, maintenance management, washing machine, DC electric motor 